\title{
Manuel José Fernández-Vinjoy y Pérez de Penafonte (traductor, canónigo y proyectista)
}

Manuel José Fernández-Vinjoy y Pérez de Penafonte (translator, canon and designer)

José Luis Pérez de Castro (Real Instituto de Estudios Asturianos)

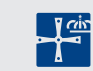




\section{RESUMEN}

Don Manuel José Fernández-Vinjoy y Pérez de Penafonte, natural de Castropol, perteneció a una noble familia asturiana, cursó estudios eclesiásticos, fue clérigo en Madrid y en 1793 se le nombró Canónigo de la Santa Iglesia Catedral de Oviedo, en donde desempeñó diversas funciones, entre otras, las de Contador Racionero Mayor y Menor. En 1794 recibió el honor y título de Caballero de la Orden de Carlos III.

Destacamos en este estudio su faceta de humanista, experto conocedor de las lenguas clásicas, culto, riguroso y elogiado traductor de las obras de Filón de Alejandría, de quien introdujo en España tres de ellas (El repúblio más sabio, El héroe estoico o el hombre libre y su Poema sagrado) por ser de utilidad para el bien común, probando que no puede haber verdadera libertad donde no domina la virtud.

Palabras clave

Castropol, traductor de Filón de Alejandría, filosofía racional, estoicismo, humanista, Jovellanos, Cabildo ovetense.

\section{AbSTRaCT}

Mr. Manuel José Fernández-Vinjoy and Pérez de Peñafonte, native of Castropol, belonged to a noble family from Asturias, he studied ecclesiastics, was a clergyman in Madrid and in 1793 he was appointed Canon of the Holy Cathedral Church of Oviedo, where he performed various functions, among others, those of Mayor and Minor Accountant Prebedery. In 1794 he received the honor and title of Knight of the Order of Charles III.

We emphasize in this study his facet of humanist, expert in classical languages, cult, rigorous and praised translator of the works of Philo of Alexandria, of whom he introduced in Spain three of them (The wisest Republican, The stoic hero or the free man and Sacred Poem) for being of utility and for the common good, proving that there can be no true freedom where virtue does not dominate.

KeY Words

Castropol, translator of Philo of Alexandria, rational philosophy, stoicism, humanist, Jovellanos, incumbent of the church from Oviedo.

Recibido: 24 de febrero de 2017. Aceptado: 27 de marzo de 2017. 
Del olvido «en el ángulo oscuro»

La personalidad de Manuel José Francisco Fernández de Vinjoy y Pérez de Penafonte resulta desconocida en la nómina de intelectuales asturianos, pues no aparece citado por González de Posada - contemporáneo suyo y como él latinista, canónigo y traductor-, por Fuertes Acevedo ni por Constantino Suárez, ni se le ha incluido en la Gran Enciclopedia Asturiana ${ }^{1}$ ni en el Diccionario Enciclopédico del Principado de Asturias ${ }^{2}$. Y lo que es aún más raro, tampoco le han mencionado siquiera los eruditos locales, siempre tan minuciosos y proclives a dignificar y enaltecer los talentos de sus coterráneos: no le prestaron la menor atención los castropolenses Manuel Pérez Pasaron y Lastra (vecino y contemporáneo suyo), José Ramón Fernández de Luanco — tan amigo y tutor de Menéndez y Pelayo, quien por cierto tampoco le incluyó en su Biblioteca de traductores españoles ${ }^{3}$ —, ni Miguel García Teijeiro, ni el presbítero José Rodríguez Fernández, ni Vicente Loriente Cancio, ni lo incluye Luis Legaspi Cortina en su nómina de personajes «castropolinos» ${ }^{4}$.

Extraña tan prolongado desconocimiento, sobre todo teniendo en cuenta que su obra la fichan algunos repertorios bibliográficos, por lo que su figura bien merece ser considerada, al menos como traductor de Filón de Alejandría, entre otros méritos que lo avalan. Ante tales omisiones, intentaré rescatarlo del olvido.

\footnotetext{
1 Silverio Cañada, José Antonio Mases y Luciano Castañón (eds.), Gran Enciclopedia Asturiana, Gijón, Gran Enciclopedia Asturiana (cito por la edición de 2006).

2 Lo desconocen Máximo Fuertes Acevedo, Bosquejo acerca del estado que alcanzó en todas épocas la literatura en Asturias, seguido de una extensa bibliografía de los escritores asturianos. Badajoz, Tipografía La Industria, 1885; Constantino Suárez, Escritores y artistas asturianos. Indice bio-bibliográfico, Madrid, 1936, t. III; y Ana María Rozas y Javier Rodríguez Muñoz (dirs.), Diccionario enciclopédico del Principado de Asturias, Oviedo, Ediciones Nobel, 2004, t. 6.

3 Sin embargo las tres traducciones de Fernández-Vinjoy figuran en la Biblioteca Menéndez Pelayo de Santander; lo que obliga a pensar que su adquisición y conocimiento por parte de don Marcelino ha sido posterior a la edición de su Biblioteca de traductores españoles (cito por la edición póstuma de Enrique Sánchez Reyes (ed.), Santander, CSIC, 1952-1953).

4 Ni José Ramón Fernández de Luanco, «Castropol» „en Fermín Canella Secades y Octavio Bellmunt y Traver (eds.), Asturias, Gijón, Fototip. y Tip. de O. Bellmunt, 1895, t. II, págs. 92-93; ni Vicente LoRIENTE Cancio, «Castropol», en la Gran Enciclopedia Asturiana, t. IV, págs. 203-204, ni Luis Legaspi Cortina, «Pórtico», en Regino Chiquirrín Agullar, Vinjoy (castropolense) su vida y su obra, Castropol, Ría del Eo, 2010, pág. 13.
} 
Ello me lleva a recordar también que en el concejo de Castropol contamos con otro traductor y sacerdote del siglo XVIII, Blas Diez — para algunos DíazCanel y Lastra, presbítero de la Orden de San Juan de Jerusalén, quien fue prior de Manzaneque en el priorato de Alcázar (Toledo) y capellán mayor en el Seminario de Nobles de Madrid, donde falleció en $1769^{5}$.

\section{Linaje de los Fernández-Vinjoy}

La estirpe de los Fernández-Vinjoy proviene del lugar de Binjoy o Vinjoy, caserío de la antigua parroquia de Piantón y hoy de la de Meredo (Vegadeo). Se les menciona ya en Moldes (Castropol) al menos en la primera mitad del XVIII, pues en 1750 prueba su nobleza ante la Audiencia de Oviedo Juan FernándezVinjoy, oriundo de Moldes ${ }^{6}$ y heredero de quienes debieron de ser los primeros quintalonguenses de este linaje (el 19 de noviembre de 1744 ya encontramos viviendo en Quintalonga a Gregorio Fernández-Vinyoy con su mujer María Josefa Pérez Penafonte). La casa de Quintalonga pertenecía por entonces a los Valledor, de quienes los Fernández-Vinjoy eran caseros, y allí continuó desarrollándose el linaje de estos hasta después de 1855, año en que Manuel Álvarez Fernández ${ }^{7}$ adquiere la propiedad.

Respecto a la estirpe y ascendencia de los Fernández-Vinjoy, no necesito retrotraerla más atrás del siglo XVII para situar a mi biografiado en aquello que ahora nos interesa. Voy a iniciarla con Blas Fernández-Vinjoy, natural de Cereijido (Piantón) e hijo de Alonso Fernández-Vinjoy. Se casó en Castropol el 16 de septiembrel679 con Isabel Vizoso Yanes Marqués, fallecida en dicha villa el 6 de noviembre de 1738, sin testar. Y allí murió su marido, también intestado, el 1 de noviembre de 1739. Ambos, empadronados como hijosdalgo en 1674, 1692 y $1704^{\circ}$. Hubieron por su descendencia al menos a Fernando Antonio Fernández-Vinjoy, nacido en Cal (Castropol) y bautizado el 31 de marzo de

5 SuÁrez, Escritores y artistas asturianos, t. III, pág. 86. Otro traductor de la Asturias occidental ha sido Agustín Bernardo Álvarez del Pato y Castrillón, que lo fue de la Secretaria de la Interpretación de Lenguas y de quien ya me ocupé en «Agustín Álvarez Pato y Castrillón, traductor en la Oficina de Interpretación de Lenguas (Illano, 1758-1843)», en Moisés Llordén Miñambres y Juan Miguel Menéndez Llana (coords.), I Congreso de Estudios Asturianos, Oviedo, RIDEA, 2007, t. I, págs. 83-112.

6 Manuel Álvarez-Valdés y Valdés, La hidalguía. Caballeros asturianos de la Orden de Carlos III, Oviedo, KRK, 1992, pág.164.

7 José Luis Pérez de Castro, «De Quintalonga (Castropol) y sus poseedores», Boletín de Letras del Real Instituto de Estudios Asturianos, 181-182 (2013), págs. 289-294.

8 Vicente de Cadenas y Vicent, «Expediente 838, aprobado el 11-X-1794», Extracto de los expedientes de la Orden de Carlos III. 1771-1847, Madrid, Hidalguía, 1982, t. IV. 
16879. Se casó en Cereijido el 16 de abril de 1721 con María López da Lastra, también conocida por María Díaz de Outeiro como natural de este lugar y por lo mismo bautizada en Piantón el 28 de agosto de 1684. Era hija de Domingo Díaz de Louteiro y Sebastiana López da Lastra, del mismo lugar ${ }^{10}$.

Don Fernando falleció el 1 de febrero de 1751. Tanto él como doña María figuran empadronados como hidalgos ya en 1736 y 1750. Hubieron por hijo, entre otros, a Gregorio Fernández-Vinjoy, quien nació en Cereijido y fue bautizado en Piantón el 12 de marzo de $1722^{11}$. Se casó en Quintalonga el 19 de noviembre de 1744 con María Josefa Pérez Penafonte y González de Tol, bautizada en Castropol el 20 de junio de 1723, hija de Juan Antonio Pérez Penafonte (nacido en Castropol el 14 de octubre de1700, hijo de Andrés Pérez Penafonte y de Mencía Rodríguez de Moldes) y de Josefa María González Anleo y Tol (nacida en Castropol 11 de marzo de 1695, hija de Antonio González de Anleo y Josefa González de Tol), quienes contrajeran matrimonio el 13 de noviembre de 1722. Era costumbre «bien frecuente» a la sazón en el occidente astur, «poner a las mujeres en todos los documentos el apellido o apellidos de las madres» en primer término, anteponiéndolos al paterno, de aquí que Josefa María utilizase González de Tol con preferencia al González de Anleo de su padre.

Don Gregorio y doña María Josefa ya figuran empadronados como tales hijosdalgos en 1766 y 1780, y hubieron varios hijos ${ }^{12}$ : entre ellos a Silvestre Fernández-Vinjoy, que sigue la línea y contrajo matrimonio con Bernarda Micaela Entrerríos, con quien tuvo cinco hijos: Manuel, Melchora, Pedro, Juan y José Antonio $^{13}$. José Antonio Fernández-Vinjoy casó con Isabel Álvarez Martínez, de quienes nacieron Manuel García, Josefa (casada con Francisco Fernández Candaosa), María (casada con Ignacio Rogína López) y a Juan Fernández-Vinjoy Álvarez, (casado con María Pérez del Trío), que falleció en 1839. Este dejó por sus hijos a Ignacia, Miguel (casado con Matilde Díaz Casariego, hija de Elías Díaz Casariego y Ana María Fernández-Vinjoy), Manuel (casado con Regina), Josefa

9 Archivo Histórico Diocesano de Oviedo, Libro de bautizados de Castropol, f. 97. Fueron sus padrinos Arango Alonso y María Basanta.

10 Fueron sus padrinos de bautismo José Padura y María Francisca Rodríguez Villamil y Piedra. Archivo Histórico Diocesano de Oviedo, Libro bautizados de Castropol de 1697, f. 96v.

11 Archivo Histórico Diocesano de Oviedo, Libro de bautizados de Castropol de 1697, f. 297v.

12 Fueron tales: José, Silvestre, Manuel José Francisco, Francisca, Josefa e Ignacia (que hubo por hijo a Miguel), Juan (de quien descienden Benito y Cándida) y Silvestre, que sigue la línea.

${ }_{13}$ En el padrón de la calle hita de Castropol, año de 1794, que se custodia en el Ayuntamiento de Vegadeo, Silvestre figura ya como fallecido y los citados hijos como tales hidalgos. A esta generación debe de corresponder también, de no ser el llamado José Antonio, el Antonio Fernández Vinjoy, mencionado en el Catastro de Ensenada, como «propietario con Maria Martínez, de un molino de un molar, que muele con dicha agua del Río de Berbesa todo el año, y produce 24 ferrados de trigo» (José Luis Pérez DE CAstro, «El Concejo de Castropol según el catastro de Ensenada», Archivum, xxvi (1976), pág. 272, respuesta 17.a). 
(casada con Francisco Candaosa), Francisco (casado con Francisca Simona de Zurazo), María (casada con Blas Fernández Candaosa), José, Antonio, Germán, Juan, Ramón, Benito, Leonardo, Fernando y Domingo Fernando Fernández Vinjoy y Pérez de Trío.

Nació este último en Quintalonga el 28 de mayo de 1828, donde sus padres eran caseros de Valledor; siendo sacerdote, se dedicó a la protección de menesterosos y desamparados. Falleció en Oviedo el 11 de abril de 1897 tras haber realizado una importante obra benéfica, aun existente, por la cual la ciudad le confirió una calle $\mathrm{e}^{14}$.

\section{Manuel José Francisco Fernández-Vinjoy}

La partida bautismal de nuestro biografiado constata su nacimiento y ascendencia como sigue:

\section{Quintalonga.}

Manuel Joseph Francisco.

En beinte y seis de maio de mil setecientos cincuenta y quatro, io Don Pedro Benito Sierra y Pamblei Cura propio de Santiago de la Villa de Castropol, bapticé con toda la solemnidad que ordena la Iglesia un niño, que nació el día beinte y quatro de dicho mes hijo legitimo de Gregorio Fernández de Vinjoy y de Maria González de Tol vecinos del lugar de Quintalon [sic] de esta Parroquia y se llama Manuel Joseph Francisco. Fueron sus padrinos, Don Joseph de la Rinoa y Urguiola y Doña Maria Francisca de Elexara y Sierra residentes en esta dicha Villa, y la madrina contrajo el parentesco espiritual. Abuelos paternos Fernando Fernández Vinjoy y Maria Fernández de Lastra, vecinos del lugar de Zereyxido parroquia de San Esteban de Piantón; maternos Juan Pérez Penafonte y Josepha González de Tol vecinos de dicho lugar de Quintalonga de que doi fe. Don Pedro Benito Sierra y Pamblei [rubricado] ${ }^{15}$.

\footnotetext{
14 Véase sobre él Domingo ChiQuirrín Aguilar, «Don Domingo Fernández-Vinjoy. Su vida y su obra», Studium Ovetense, 14 (1996), págs. 15-76. Este trabajo ha sido recogido años después en el ya citado volumen editado por la Fundación Ría del Eo y publicado por Cajastur en 2010, con 117 páginas. La Fundación Vinjoy continúa en actividad: Andrea SuÁREZ «Vinjoy apoyará a universitarios asturianos con discapacidades. La institución y la universidad colaboran en facilitarles los estudios con especial atención a los que padecen sordera», La Nueva España, Oviedo, 10 de julio de 2008, pág. 40. Elena Fernández-PelLo, «La fundación Vinjoy hace historia y repasa su actividad en esta década», La Nueva España del Occidente, Oviedo, 22 de junio de 2010, pág. 5 . Y otros.

15 Archivo Histórico Diocesano de Oviedo, 14.3.3, Libro de bautizados de 1763 a 1764 de la Parroquia de Santiago de Castropol, f. 79.
} 
Como ya expusimos, fueron sus bisabuelos paterno-paternos Blas Fernández Vinjoy e Isabel Vizoso Yanes Marqués, y los paterno-maternos Domingo Díaz de Outeiro y Sebastiana López de Lastra. En cuanto a la rama materna fueron sus bisabuelos paternos: Andrés Pérez Penafonte y Mencía Rodríguez de Moldes y los maternos Antonio González de Anleo y Josefa González de Tol.

Manuel Fernández-Vinjoy, quien separó en dos ese apellido compuesto, aun residiendo en otros lugares como Madrid y Oviedo continuó empadronado en Quintalonga, y así consta en los padrones de nobleza de Castropol de 1794 y 1825. Y mantuvo la tradición de venir desde Oviedo a pasar temporadas en dicha casa castropolense, ocupando en ella el ala izquierda, donde estaba el salón y en la cual persiste una alcoba denominada «del canónigo» ${ }^{16}$.

\section{Clérigo en Madrid y humanista}

No he podido localizar aún dónde realizó sus estudios eclesiásticos Fernández Vinjoy, pero como los aspirantes al sacerdocio procedentes del occidente astur solían ir a cursar la carrera generalmente a los seminarios de Oviedo o Mondoñedo (Lugo), intenté averiguarlo siguiendo dichas pistas. Sin embargo, debido a la pérdida de los archivos del primero, no pude obtener datos al respecto, como tampoco obtuve éxito con las pesquisas que llevé a cabo en los seminarios mindonienses. No obstante, sospecho que pudo haberse formado en Madrid, ya que en esta capital vivía en marzo de 1788 y en 1790, cuando eleva su primera súplica al conde de Floridablanca, José Moñino y Redondo (17281808). En Madrid realiza y fecha sus traducciones de Filón y de dicha capital salió nombrado Canónigo para la Catedral de Oviedo. Pero por ahora tampoco he podido confirmar si en Madrid prestaba algún otro servicio además de ser clérigo de menores incongruo, es decir, ministro de la Iglesia inferior a los diáconos, que no percibía congrua, o sea, la renta que debe tener el que se ha ordenado in sacris.

La preparación de Fernández Vinjoy era sin duda la de un humanista, y lo afirmo no solo por traducir el griego y latín sino además por ser un estudioso de Filón de Alejandría (c. 15 a. C.-45 d. C.), la figura más destacada del movimiento filosófico judeo-alejandrino y gran seguidor de la doctrina platónica (por lo que era conocido como el «Platón hebreo»). Recordemos el proloquio «Platon Filoniza o Filón Platoniza».

16 Manifestación que me hizo Pedro Pardo Álvarez, uno de los penúltimos poseedores de la casa de Quintalonga. 
En 1788 el propio Fernández Vinjoy le biografió y juzgó en su «Advertencia», que precede a la traducción de El Repúblico ${ }^{17}$, si bien en ella se contentaba con «darlo únicamente a conocer por la fama de su nombre». Un año después en el «Plan del presente Discurso y breves noticias de su autor», que antepuso a su traducción de El héroe Estoico, o el héroe libre, realizó varias demostraciones «del gran carácter con que se ha distinguido» y expuso con deleite y admiración el contenido de la obra. Pero no es mi propósito actual analizar los juicios de Vinjoy acerca de la personalidad y la obra de Filón, y menos compararlos con los de otros biógrafos filonienses e historiadores de la filosofía y del pensamiento. Pretendo simplemente destacar que para Fernández Vinjoy el estilo de Filón resulta «prolijo, pesado, fatigoso, lleno de divagaciones y hasta de incongruencias y contradicciones» forzadas por su eclecticismo filosófico ${ }^{18}$, lo cual dificulta enormemente la traducción. Sin embargo, Fernández-Vinjoy sintió por él una gran admiración; como lo demuestra el haber traducido al menos dos de sus obras.

\section{Traductor de griego y latín}

El primer texto de Filón traducido y publicado por Fernández Vinjoy, del cual por ahora tenemos noticia, fue El Repúblico más sabio ${ }^{19}$. Palau registra esta obra por partida triple con distintas características y paginación. La primera, con el título abreviado y con 226 páginas, en octavo. La segunda, también en octavo pero con 8 hojas y 513 páginas. Mientras, Aguilar Piñal ficha una sola edición con 8 hojas +211 páginas en tamaño de $15 \mathrm{~cm}^{20}$. Palau, por

17 Hablaremos de las obras del traductor más por extenso en el siguiente epígrafe, en el que nos ocuparemos entre otras cosas de referenciar adecuadamente sus ediciones.

18 Para conocer los principios más probables y la crítica casi contemporánea de la filosofía de Filón puede consultarse: Zeferino González y Díaz Tuñón, Historia de la filosofía, Madrid, Imprenta de Policarpo López, 1878, t. I, págs. 405-409. Más actuales son Guillermo Fraile, Historia de la filosofía. Grecia y Roma, Madrid, Biblioteca de Autores Cristianos, 1956, págs. 674-683; y Jean DaniéLou, Ensayo sobre Filón de Alejandría, Madrid, Taurus, 1963.

19 La referencia íntegra es como sigue: El repúblico más sabio. Historia del hombre civil, el Patriarca Joseph el Casto. Sacada de los capítulos del Génesis 37 hasta el 50, y fin del libro, por el muy ilustre hebreo Filón, y que publica en nuestra lengua Don Manuel Joseph Fernández Vinjoy. Madrid, D. Joseph Doblado, 1788, en la Librería de Barco a 10 reales en pasta.

20 Antonio Palau y Dulcet, Manual del librero hispanoamericano. Bibliografía general española desde la invención de la imprenta hasta nuestros tiempos con el valor comercial de los impresos descritos, Barcelona, 1951, t. V. Cita la primera en la pág. 351, ref. ${ }^{\text {a } 89.965, ~ y ~ l a ~ s e g u n d a ~ e n ~ l a ~ p a ́ g . ~ 400, ~ r e f . ~}{ }^{\text {a }} 91.617$; lo cual nos hace pensar que no tuvo ejemplar alguno a la vista y citó de segunda mano, por cuanto esas tres referencias no coinciden con la de Aguilar Piñal, Bibliografía de autores españoles del siglo XVIII, Madrid, Csic, 1984, t.

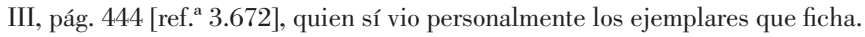


su parte, cita también una segunda edición impresa igualmente en Madrid en 1816, en cuarto, con solo 38 páginas y al precio de 10 pesetas en $1910^{21}$.

Esta versión del traductor se inicia con una «Advertencia importante al que leyere», en la cual expone la grandeza del pensamiento de Filón y explica cómo este da las más obvias reflexiones para la inteligencia de las Leyes y su uso, y las reglas más oportunas para el acierto en los diferentes cargos e inopinados lances a que por lo arduo de su oficio se expone todo «repúblico» o presidente jurídico, juntamente con otras instrucciones y análisis. Sobre todo nos interesa destacar cómo el propio Fernández Vinjoy manifiesta que su versión «en algunos lugares es libre y aun parafrásica; pues solo procuramos ceñirnos a lo literal del texto quando hemos advertido que éste no sonaba con flojedad o dureza en nuestra lengua».

Finalizada la traducción, Fernández Vinjoy buscó, como era usual, poner la obra bajo el patrocinio de algún poderoso y el 12 de marzo de 1788 redactó la carta y dedicatoria al conde de Floridablanca ${ }^{22}$, a quien se la remitió al día siguiente precedida de otra misiva:

\section{Excmo. Señor}

Manuel Joseph Fernández Vinjoy, Clérigo de Menores, con el mayor respeto hace presente a V. E.; que el quebranto de salud que padece, le impide tener la grande honra de poner personalmente en manos de V. E. la inclusa obra. Esta es Señor, uno de los bellos rasgos que en idioma Griego nos ha dejado el insigne Judío Filón y vertida por primera vez en nuestra lengua, va buscando acogida en la poderosa protección de V. E. a quien por el adjunto Discurso la ofrece y la consagra el exponente.

Y por quanto, Señor, está suspensa su publicación hasta el logro de la resolución de V. E., espera se digne favorecerle, insinuándosele propicio por el medio que fuere mas del agrado de V. E.

Dios nuestro Señor conserve la importante vida de V. E. en el auge de su Grandeza m. a. Madrid y marzo 13 del 1788.

Excmo. Señor. / B.L.M.D.V.E. / Manuel Joseph Fernández Vinjoy, rubricado ${ }^{23}$.

La petición que acompañaba a la carta anterior decía:

$21 \quad$ Palau y Dulcet, Manual del librero hispanoamericano, pág. 400 [ref. ${ }^{\text {a }} 91.618$ ].

22 Asturias conmemoró el bicentenario de la muerte de Floridablanca con el tomo de estudios Jesús Menéndez Peláez (coord.), José Moñino y Redondo, conde de Floridablanca (1728-1808). Estudios en el bicentenario de su muerte, Gijón, Fundación Foro Jovellanos, 2009. Este volumen contiene una abundante bibliografía sobre el mismo en las págs. 327-331.

23 Copia de la carta en mi archivo particular. 
Al Excmo. Señor Don Joseph Moñino, Conde de Floridablanca, Caballero Gran Cruz de la Real y Distinguida Orden de Carlos III, su Consejero y primer Ministro de Estado y del Despacho Universal, y Encargado interinamente del de Gracia y Justicia, etc. etc.

\section{Excmo. Señor}

El Retrato de un Sabio y verdadero Ministro que en la Historia del gran Patriarca Josef nos ha representado el erudito Filón con el valiente pincel de su delicada pluma, por muy antiguo que se le considere, ninguno podrá negar, que tiene un original tan nuevo, como en el día se experimenta en la conducta práctica de las operaciones gloriosas, con que V. E. se ha dado a conocer al Mundo todo. Tendría ciertamente por inútil declarar una verdad, que a pública voz (y aun en las conversaciones más secretas, en que se suele hablar con libertad lo que se siente) esparce sonoramente la fama, y la opinión de V.E. Por lo mismo intento limitarme, diciendo solamente la diferencia que hallo entre uno y otro Josef. Consiste, pues, en que aquel, para llegar a tan alta cumbre de Honor y de Dignidad, pasó por medio de los mayores trabajos y persecuciones, que más le habilitaron, para a darle a conocer, y conociese. Pero V. E., sin otras pruebas que las de sus muy honrosos cargos, hizo brillar por los grados, del Honor las luces de su Sabiduría y Prudencia consumada: brillantes mas de día en día, quanto eran mas dilatados los enanches que tomaban; al modo que el Astro de primera magnitud, entonces ilumina mas al Orbe, quando al Zenit se remonta mas apresurado por la Eclíptica de su carrera.

Se muy bien, Señor, que estoy muy lejos de la lisonja en esta, y semejantes expresiones que no quiero particularizar; y que con todas ellas, quedándome con precisión muy corto, me hallaría distante de turbar la modestia que en los ánimos de singular Grandeza, como es sin duda el de V. E., se hace superior a todo elogio, y persiste en su asiento sin la menor mudanza.

La única recomendación que pudiera hacer aceptable a esta pequeña obra en la Dignación de V. E., es la de haber sido empeño de un Autor, cuyo nombre fue, y será celebrado de todos los Sabios, y aun imitado por los primeros Padres de la Iglesia. Sola mi insuficiencia para la versión, la privará de su gran mérito en mucha parte. Con todo me asiste la esperanza de que V. E. se ha de dignar atenderla en el afecto con que he deseado fuese, como debía, muy acertada y perfecta. Siendo esto así, no dudo que los preceptos y consejos que en ella se descubren, hagan patente a V. E., como al antiguo Joseph, por absoluto Ejemplar a toda suerte de Repúblicos, cuya bondad es indispensable para la tranquilidad y aumento de los Pueblos, y Cuerpos asociados, que gobiernan.

Bien podemos oír los Españoles, que nos dice nuestro muy Augusto Católico Monarca lo que a los Egipcios respondía su Rey en las peticiones y consultas 
que la hacían: Ite ad Joseph \& quidquid ipse vobis dixerit, facire (Génesis cap. 41 y ss.). Así es, Señor, pues el gran Carlos, para el mayor acierto en todas sus admirables empresas, no tiene satisfacción mas oportuna, que la fundada en la vigilancia y sabia economía con que beneficia V. E. al Común y Particulares de su alto Ministerio; sin que haya quien se esconda del calor de sus penetrantes luces, por mas elevados que se descubran los montes, y por mas profundos que se retiren los valles. Esta es a la verdad la causa que me ha dado aliento para tributar mis respectos en obsequio de V. E., cuya importante Vida prospere el Rey del cielo para continuo Aumento de la Española Monarquía.

Madrid y marzo 12 de 1788.

Excmo. Señor. / B.L.M.D.V.E. / Su muy reverente Servidor, y menor Capellán de V. E. / Manuel Joseph Fernández Vinjoy²4.

Tres días después de recibida dicha dedicatoria, Floridablanca, harto sin duda de tales peticiones, despachó el expediente el 16 de marzo, limitándose a escribir en la carpetilla del mismo: «Le estimo la dedicatoria pero que la excuse, pues sin ella le atenderé según su mérito».

Fernández Vinjoy, contento con tan simple atención, se la agradece con esta otra misiva:

Excmo. Señor

Manuel Joseph Fernández Vinjoy con el debido respeto da a V.E. las más expresivas gracias por el extremado honor que V.E. fue servido hacerle, favoreciéndole el 16 del cte. con su resolución (sumamente apreciable con toda su latitud) acerca de la dedicatoria. Sin este adorno, Señor, saldrá luego a la luz pública la Historia de Joseph: y ha parecido al que expone muy propio de su obligación, y digno de su gratitud dirigir a V. E. otro ejemplar más decente con el objeto de que, colocado en la librería de V.E. se perpetúe en ella su reconocimiento a tanto favor y honor tanto.

Dios nuestro Señor conserve la importante vida de V.E. en el auge de su Grandeza m. a. Madrid 30 de marzo de 1788.

Excmo. Señor B. L. M. D. V. E. Manuel Joseph Fernández Vinjoy ${ }^{25}$.

No obstante el desdén del conde de Floridablanca, la versión de Vinjoy fue acogida por la crítica con elogio. El Memorial Literario recalcaba que

24 Copia de la carta en mi archivo particular.

25 Copia de la carta en mi archivo particular. 
[U]na de las obras mas recomendables del erudito y eloquente Filón es la presente Historia, no solo por el artificio y elegancia con que está escrita, sutileza de pensamientos; y gran variedad de imágenes y figuras con que se adorna y ameniza; mas también porque teniendo mucho que aprender en ella el que intente ser un buen republico, no tendrá menos que admirar al Retórico, al Poeta, y al Historiador y generalmente toda clase de Lectores que medite su admirable doctrina. El expositor Sagrado hallará un práctico exemplo de que se han valido los primeros PP. de la Iglesia para el uso de las alegorías en la exposición de la Escritura Santa; pues por este medio en el nombre de Joseph, en la tradición de los hermanos; en la victoria que alcanzó de la muger impura, en la prisión que padeció; y en los sueños que interpretó hasta que elevado al honorífico empleo de primer Ministro del Rey, dio las mejores pruebas para la conducta de un Republico; prescribe Filón las significaciones que halló su ingenio en la alegoría, para aplicarlas con oportunidad a su intento ${ }^{26}$.

Aparte de ese elogioso comentario a la obra en si misma, diversos autores han visto y acogido las traducciones de Fernández Vinjoy con el elogio merecido. Baste citar a Arturo Sandoval y Abellán, quien no ha reparado en declarar que «[e]l Excmo. Sr. D. Manuel Fernández Vinjoy [...] estaba muy versado en lengua griega» ${ }^{27}$. Y Sánchez Caro, Rector de la Universidad Pontificia de Salamanca, señala que «[d]esde otra perspectiva es significativo el largo titulo, de sabor ilustrado, que da Manuel José Fernández Vinjoy a su obra sobre el patriarca José en 1788: El Repúblico mas sabio: historia del hombre civil, el patriarca Joseph el Casto. [...] Conviene notar que el autor, por otros libros publicados, parece conocer suficientemente el griego. Su caso, no cabe duda, es singular en el conjunto de textos reseñados ${ }^{28}$.

Por otro lado, Jovellanos escribiría el 11 de julio de 1796 en su Diario el siguiente resentido e inmerecido comentario: «Lectura en El Repúblico mas sabio; de Don Manuel Fernández Vinjoy; es una traducción de Filón, el Judío, dice que la hizo sobre la versión latina; pero con presencia del original griego. ¿Le entiende acaso? Como yo» ${ }^{29}$. No debe extrañarnos tan innecesaria crítica, al

${ }_{26}$ Memorial Literario, Instructivo y Curioso de la Corte de Madrid, t. XIII (1788), pág. 603.

27 Arturo de Sandoval y Abellán, La grandiosa empresa de la independencia y el Cabildo Catedral de Oviedo, Oviedo, Tipografía Uría Hermanos, 1908, pág. 81.

28 José Manuel Sánchez Caro, Biblia e ilustración. Las versiones castellanas de la Biblia en el Siglo de las Luces, Vigo, Editorial Academia del Hispanismo, 2012, pág. 51.

29 Gaspar Melchor de Jovellanos, Obras Completas, t. viI, Diario, $2^{\circ}$, , Maria Teresa Caso Machicado y Javier González Santos (eds.), Oviedo, Instituto Feijoo de Estudios del Siglo XVIII / Ayuntamiento de Gijón, 1999, pág. 557. En Julio Somoza (ed.), Diarios de Jovellanos (memorias íntimas), Oviedo, RidEA, 1953-1954, t. II, pág. 261, Somoza confunde El Repúbiclo más sabio y El héroe estoico, lo que es advertido en Jean-Pierre 
cabo de ocho años, pues es conocido el menosprecio y juicio despectivo con que Jovellanos aludía y aplicaba receloso a cuantos no compartían sus opiniones, diferían de sus planes, o podían afectar a Gijón; y siempre a sus espaldas, como ya he apuntado al respecto de su actitud hacia Martínez Marina ${ }^{30}$. Cabe suponer que Jovellanos no habría podido olvidar aún la oposición que Fernández Vinjoy le había hecho en su proyecto acerca del trazado de la carretera de Asturias a Castilla que, como veremos, se resolvió favorable a Jovellanos en 1795: de ahí que al año siguiente se le ocurriese revisar la versión o traducción del canónigo para censurarlo.

Pese a tal juicio, la traducción de Fernández Vinjoy alcanzó la debida consideración, según él mismo recordaba con estas palabras:

La grande aceptación con que el publico recomendó la traducción que hicimos del libro de Filón, y titulamos El Republico más Sabio, nos sirvió de estímulo para consagrar, no sin utilidad propia, los momentos necesarios a la versión de este muy ingenioso y elegante Discurso, que intitulo Filón: El Libre; y nos pareció que le declarábamos oportunamente, entendiendo por él al Héroe Estoico.

En efecto, alentado por aquel éxito, emprendió la traducción de $E l$ héroe estoico o el hombre libre ${ }^{31}$. A la traducción ${ }^{32}$ la precedió un «Plan del presente Discurso y breves noticias de su autor» que ocupa las paginas III a XXXII. Ha de destacarse que la labor de Vinjoy haya merecido la correspondiente reseña en el Memorial literario donde, tras la ficha puramente bibliográfica, se comenta

El abuso común de la esclavitud civil, que tenía opresa la mayor parte de los hombres, en el tiempo en que florecía Filón, le movió sin duda para extinguir tan horrenda costumbre a escribir este tratado, haciendo ver en él «que el esclavo

CLÉMent, Las lecturas de Jovellanos (ensayo de reconstitución de su biblioteca), Oviedo, RideA, 1980, ref. ${ }^{\text {a }} 561$, pág. 116.

30 José Luis Pérez de Castro, El Diccionario Geográfico-Histórico de Asturias dirigido por D. Francisco Martínez Marina, Oviedo, RidEA, 1959, t. 1, págs. 61-66.

31 El título completo es El héroe estoico o el hombre libre. Discurso en que se prueba, que no puede haber verdadera libertad donde no domina la virtud: escrito en griego por el muy sabio y erudito Filón; y traducido al español para la común utilidad lo pública Don Manuel Joseph Fernández Vinjoy. Madrid, Don Gerónimo Ortega e hijos de Ibarra, 1789. Edición que Palau registra en octavo, con XxxII + 128 páginas, de $15 \mathrm{cms}$.

32 Palau y Dulcet, Manual del librero hispanoamericano, pág. 400, [ref. a 91.619], y de la cual Aguilar Piñal (Bibliografía de autores españoles del siglo XVIII, t. 3, pág. 444, [ref. a 3.673]) también halló ejemplares en la Biblioteca Nacional de Madrid y en la Menéndez Pelayo de Santander. Otra descripción igual figura en el Catálogo de «Fernando Durán. Libros y manuscritos» para la subasta de los días 14 y 15 de noviembre de 2001, en la página 23 con el n. ${ }^{\circ} 307$. 
o el tenido por tal en el vulgo, puede ser mas libre que su dueño» mezclando al mismo tiempo, para atraer a sus lectores a la virtud, peregrinas especies, con las que quiso merecerse la aceptación de los gentiles contrarios a su religión ${ }^{33}$.

Así pues, Fernández Vinjoy fue pionero en verter al español e introducir en España la obra de Filón, y éste a su vez uno de los autores menos traducidos a nuestro idioma al haber sido tachado por los expurgatorios de la Inquisición. También le corresponde a Vinjoy el mérito de haber divulgado entre nosotros la importancia de la obra de Filón, que «más que un sistema coherente constituye un sincretismo, en que sobre el fondo judío, yuxtapone elementos platónicos, estoicos, pitagóricos, aristotélicos, cuidando poco de armonizarlos entre sí» y «representa un esfuerzo para armonizar la Filosofía racional con la religión revelada, primera manifestación de un problema, que veremos repetido en el neoplatonismo, que intentará la alianza entre la Filosofía y la mitología pagana, después en la Filosofía árabe y mas tarde en la escolástica cristiana» ${ }^{34}$.

La gran acogida de crítica que obtuvieran las dos anteriores traducciones, animó a Fernández Vinjoy a emprender una tercera, sobre otra obra del propio Filón, el Poema sagrado ${ }^{35}$.Sobre ella ${ }^{36}$ apareció también reseña en el Memorial Literario $^{37}$, donde tras la ficha puramente bibliográfica, se comentaba: «Trátase en este librito de la obligación que tiene el hombre de dirigir sus obras a Dios por sus preceptos. Del primer precepto del decálogo, de la contrariedad del bien y mal, de la lascivia, envidia, avaricia, opulencia, limosna, paz, soberbia, gula, pereza, etc.».

E igualmente en la Gaceta de Madrid se publicó este otro anuncio, más extenso y explícito:

Poema Sagrado: Carta Pastoral que el ínclito español San Orencio, Obispo, compuso en verso heróyco latino, y dirigió a los fieles de su Diócesis Iliberitana, con

33 Memorial Literario, Instructivo y Curioso de la Corte de Madrid, t. Ix (1789), págs. 99-100.

34 Fraile, Historia de la filosofía, págs. 674-675.

35 En portada se lee: Poema sagrado. Pastoral del español insigne San Orencio Obispo, que compuesto en verso heroico y latino dirigió a los fieles de su Diócesis Iliberitana con el titulo Commonitorium y traducido en verso castellano, para la instrucción común, lo publica Don Manuel Joseph Fernández Vinjoy. Madrid, Gerónimo Ortega e hijos de Ibarra, 1790. Edición en cuarto. XVI + 47 páginas.

36 Palau y Dulcet, Manual del librero hispanoamericano, t. XIX, pág. 200 [ref. a 293.247]. El autor se preocupa en la pág. 199 de que no se confunda al San Orencio de Granda con su coetáneo de igual nombre, el Obispo de Auch. En Aguilar Piñal, Bibliografía de autores españoles del siglo XVIII, t. 3, pág. 445 [ref. ${ }^{a}$ 3.674] se dice que hay ejemplares en la Biblioteca Nacional de Madrid, en la del Consejo Central, así como en la Menéndez Pelayo de Santander. El autor consultó el expediente que al respecto obra en AHN, Estado, leg. $3.238(9)$.

37 Memorial literario, t. VII (1790), págs. 365-366. 
el titulo Commonitorium. Este rasgo sublime, que es y será un monumento del gran zelo y del inmenso caudal de la elocuencia de su venerable autor, que floreció al fin del quinto siglo de la Iglesia y principio del sexto, y a quien califica de noble ingenio el Cardenal Cesar Baronio, es obra utilísima a toda clase de personas, y muy recomendable por su estilo, tanto mas enérgico quanto mas sencillo, con que persuade el amor que se debe a Dios y al próximo, y con que retrata el horror y de los vicios capitales, y el esplendor de las virtudes contrarias: y para el común aprovechamiento y justa declaración del relevante merito de un Santo Obispo Español, cuya antigüedad que consiste casi en trece siglos tuvo obscurecida su feliz memoria, lo saca a luz traducido en verso Castellano D. Manuel Joseph Fernández Vinjoy, quien lo dedica al buen Pastor, cuya estampa grabada primorosamente va colocada al principio de cada ejemplar: un tomo en $4 .^{\circ}$. Se hallará con el Héroe Estoico o el Libre, del muy erudito Hebreo Filón, la lámina del Buen Pastor suelta, y demás obras del editor, en la librería de Ortega, calle angosta de Majaderitos, frente el Coliseo de la Cruz; en la del Barco, Carrera de S. Jerónimo; y en Oviedo en casa de Acero $^{38}$.

Con motivo de esta nueva obra, Fernández Vinjoy volvió a implorar el auxilio del conde de Floridablanca mediante la siguiente petición del 16 de junio de 1790:

Excmo. Señor Conde de Floridablanca

Señor Excmo.

Don Manuel Joseph Fernández Vinjoy tiene la honra de dirigir a manos de V.E. un exemplar del Commonitorio de S. Orencio, que ha traducido en verso castellano del heróico latino, y acaba de imprimir. Espera sea del agrado de V. E. tal insinuación.

Y por quanto los Directores de la Compañía de Filipinas toman a cuenta de esta partida de ejemplares a los editores que tienen recomendación, a fin de conducirlos a Yndias donde todo libro se despacha, según dicen, ventajosamente; el exponente que con motivo de las dos ultimas impresiones contraxo la deuda de 5500 r. de vellón, que le tiene en bastante conflicto, necesita para salir de él, que dichos Directores le tomen el número de exemplares que expresa el memorial que formado para ellos, se atreve a incluir a V. E., suplicando rendidamente a su gran piedad se digne recomendárselo del modo que mas fuere de su agrado; pues la mas leve insinuación de V.E. será el mas eficaz medio para que este pobre clérigo incongruo logre el efecto que apetece.

38 Gaceta de Madrid, 46 (8 de junio de 1790), pág. 392. 
Gracia que el suplicante se promete de la innata conmiseración de V.E. cuya importante vida prospere el Cielo Dilatados años Madrid, 16 de junio de 1790.

Excmo. Señor / B. L. M. D. V. E. / Manuel Joseph Fernández Vinjoy ${ }^{39}$.

Y el 30 de julio le remitió la siguiente carta:

Commonitorio de S. Orencio

30 de julio de 1790

Excmo. Señor.

D. Manuel Joseph Fernández Vinjoy presenta a V. E. un exemplar del Commonitorio de S. Orencio que ha traducido en verso castellano; y suplica a V. E. que se sirva recomendar a los Directores de la Compañía de Filipinas un memorial que acompaña en solicitud de que se tomen mil exemplares por mitad de dicha obra y de la del Héroe Estoico a fin de salir con su importe de una deuda de 500 duc. que ha contraído en sus impresiones ${ }^{40}$.

Carta a la cual el conde dio el mismo 30 de julio otra respuesta no menos lacónica y desafectiva que a la primera: «Enviarla para que hagan el uso que les convenga».

Con respecto a la labor de Fernández Vinjoy, es de destacar cómo las tres obras reseñadas las realizó y costeó por su propia iniciativa; de ahí, tal vez, que no hiciese constar en la portada de las mismas quién era el traductor, sino simplemente que era él quien las publicaba, y únicamente «[p]ara la común utilidad». Pese a que omitiera ser el traductor, no esta de más resaltar que traducir no es tarea sencilla, y menos a autores con prosa tan enrevesada e ideas tan complejas como las de Filón. Porque verter un texto a otro idioma no implica limitarse al significado equivalente de las palabras; pues cada oración lleva implícita matices y efectos muy sutiles que «dan vida al movimiento e individualidad al texto», lo cual se dificulta cuando hay giros y expresiones que no siempre tienen equivalencia en otros idiomas. Unamos a esto que no todo traductor tiene su sentimiento e ingenio en consonancia con los del autor, por lo cual ha de esforzarse en penetrar esa esencia y aun en transmitirla al nuevo texto. De ahí que existan traducciones puramente literales, donde prima el mero significado de cada palabra; y otras libres, donde el espíritu creativo del traductor, para vivificar el texto, ha de estructurar las frases con igual calidad y fuerza que en el original; procurando que la nueva versión no desencaje de la

39 Copia de la carta en mi archivo particular.

40 Copia de la carta en mi archivo particular. 
primigenia. Para ello, ha de ser fidedigno, concienzudo y fehaciente, al punto de respetar época y ambiente en los que obra fue escrita; y más escrupuloso aún, si cabe, tratándose de obras literarias, dialogadas y filosóficas. Lo cual implica en quien traduce un similar conocimiento tanto del idioma original como de aquel al cual se vierte ${ }^{41}$. Si bien insisto en que lo importante en el traductor no consiste solo en conocer el idioma, sino también en penetrar en el contenido del texto extranjero, en saber explorarlo y trasladarlo con el garbo, interés e intenciones del autor, adecuando las significaciones alternativas de ambos idiomas. Dotes muy escasas e intransferibles.

Insisto en que por tales dificultades los méritos de los traductores han sido resaltados diversas veces, e incluso se realizaron catálogos sobre los mismos, como por ejemplo los de Juan Antonio Pellicer, Menéndez y Pelayo o modernamente Esther Benítez ${ }^{42}$. Sería deseable que alguien se ocupase de recopilar un diccionario de cuantos traductores asturianos han participado en la «difícil, ingrata y nunca bien premiada tarea de trasladar las joyas de otras literaturas a la lengua patria ${ }^{43}$, contribuyendo no solo a su difusión sino además poniendo al alcance de nuestros estudiosos las obras de los grandes escritores y científicos de otras naciones.

Como ya han resaltado entre otros Inmaculada Urzanqui y Álvaro Ruiz de la Peña, las traducciones han sido siempre una de las vías de intercambio y enriquecimiento cultural para cualquier país, también en el nuestro, donde «forman un capítulo importantísimo de la Ilustración española, por desgracia aún no estudiado más que muy parcialmente». Además, casi nunca responden a la «simple actividad de pane lucrando» sino «a lo que es la aspiración y norte de toda su tarea intelectual: ilustrar a los españoles» ${ }^{44}$.

${ }^{41}$ A este respecto pueden consultarse los textos de traductores y comentaristas tales como Francisco Ayala, Problemas de la traducción, Madrid, Taurus, 1965; Georges Mounin, Los problemas teóricos de la traducción, Madrid, Gredos, 1971; Valentín García Yebra, En torno a la traducción: Teoría. Crítica. Historia. Teoría y práctica de la traducción, Madrid, Gredos, 1983; Jean MaILlot, Traducción científica y técnica, Madrid, Gredos, 1997; entre otros.

42 Juan Antonio Pellicer y Saforcada, Ensayo de una biblioteca de traductores españoles donde se da noticia de las traducciones que hay en castellano de la Sagrada Escritura, Santos Padres, Filósofos, historiadores, médicos, oradores poetas así griegos como latinos y de otros autores que han florecido antes de la invención de la imprenta. Preceden varias noticias para la vida de otros escritores españoles, Madrid, Antonio de Sancha, 1778; Menéndez y Pelayo, Biblioteca de autores españoles; y Esther Benítez (coord.), Diccionario de traductores, Madrid, Pirámide, 1992; ente tantas.

43 Rafael de Balbín Lucas y Enrique Sánchez Reyes, «Advertencia» a la edición de Menéndez y PeLAYo, Biblioteca de traductores españoles. En un aspecto de dicha recopilación cabe citar a Ramiro GONZÁLEZ Delgado, «Les traducciones d'Horacio al asturiano», Lletres Asturianes. Boletín Oficial de l'Academia de la Llingua Asturiana, 85 (2004), págs. 57-84, y la bibliografía que incluye en las págs. 83-84.

44 Inmaculada UrzainQui y Álvaro RuIZ de la PeÑa, Periodismo e ilustración en Manuel Rubín de Celis, Oviedo, Centro de Estudios del Siglo XVIII, 1983, págs. 31-32. 


\section{Caballero de Carlos III y Canónigo}

En 1793, Fernández Vinjoy fue nombrado por su Majestad canónigo de la Santa Iglesia Católica de Oviedo para cubrir la vacante dejada por fallecimiento de Pedro Fernández ${ }^{45}$. No he podido concretar por ahora si fue canónigo de gracia, por mero nombramiento del gobierno o del cabildo, o de oficio, es decir, por oposición.

Una vez electo y antes de tomar posesión del cargo, era preceptivo y habitual practicar las reglamentarias pruebas de genealogía y limpieza de sangre, y así se hizo en el caso de Fernández Vinjoy ${ }^{46}$. A este fin, el 4 de junio se eligió juez capitular informante al penitenciario don Manuel Díaz de Miranda —en Castropol comparecería como juez de comisión al efecto Benito Antonio de Prado y Valdés-. Realizada la compulsa documental correspondiente en los libros sacramentales y empadronamientos, y recibida la prueba testifical de vecinos a fe del escribano Manuel Pasaron, se declara que los ascendientes de Fernández Vinjoy por ambas ramas

[...] fueron cristianos viejos, limpios, y de sangre no solo limpia sino también noble, como que todos fueron y son notorios hijosdalgo, sin mácula de raza de moros, judíos, herejes, reconciliados, confesos, ni penitenciados por el Santo Oficio de la Inquisición ni de otro Tribunal, ni que hayan sido ni fueron tocados, ni comprendidos en nota alguna de infamia, y antes bien gozaron de la mas plena fama de tales cristianos ${ }^{47}$.

45 Gaceta de Madrid, 19 (5 de marzo de 1793), pág. 166.

46 El problema y «error español» de los estatutos de limpieza de sangre aplicados por las instituciones eclesiásticas, y en concreto por las Iglesias Catedrales, ya desde comienzos del siglo xvi, estaba fuera del orden natural de las cosas, pues impedía ingresar en ciertos cargos a personas bien dotadas, y provocaba un encantamiento social no solo frente a los conversos sino también a otras castas; de ahí su connotación «aristocratizante» y «acaballerarse». No obstante, como hecho histórico se puede consultar Juan Ignacio GuTIÉRREZ NiETo, «Los conversos y la limpieza de sangre en la España del siglo XVI», Torre de los Lujanes, 26 (1994); para el XVIII, véanse entre otros, Baltasar Cuart Moner, Colegiales mayores y limpieza de sangre durante la Edad Moderna, Salamanca, Servicio de Publicaciones de la Universidad de Salamanca, 1991, págs. 68-73. Resumen en parte su doctrina Álvarez-V Aldés y Valdés, La hidalguía, págs. 35-114; y Adolfo Carrasco MarTínez, Sangre, honor y privilegio. La nobleza española bajo los Austrias, Barcelona, Ariel, 2000.

${ }_{47}$ Se encuentra su expediente en el Archivo de la Catedral de Oviedo, Libro 14, Expediente n. ${ }^{\circ} 8$ (1793) Probaron igual limpieza e hidalguía ante la Real Audiencia de Oviedo Ignacio Fernández Vinjoy González Tol y Fernández Pividal, vecino de San Juan de Priório (Oviedo), aunque natural y oriundo de Castropol, y Juan Fernández Vinjoy, hijo de Miguel y nieto de Francisco, oriundos de San. Juan de Moldes y también vecino de Oviedo el 20 de agosto de 1794, así como sus ascendientes Blas, Fernando y Gregorio (información extraída de Vicente de Cadenas y Vicent, Índice de apellidos probados en la orden de Carlos III. Antecedentes de otros que se conservan en sus expedientes. Madrid, Ediciones Hidalguía, 1965, pág. 152. [Exp. 838, n. $\left.{ }^{\circ} 876\right]$ ). 
En consecuencia, en el Cabildo del 7 de agosto de 1793, se acordó «llamar ante diem para leer las pruebas de don Manuel Josef Fernández Vinjoy», lo cual se hizo en el día 9; y, con el penitenciario como informante, presentaron las que se hallaban hechas con las solemnidades y formalidades de rigor y aprobaron con gracias a dicho señor. En su virtud, nombraron a los señores tesorero, magistral y doctor para darle la posesión, que con el señor prior, apoderado de dicho Vinjoy, y acompañados por el secretario, pasaron a la iglesia para ejecutarlas en el coro.

Sentado dicho poderhabiente en la ultima silla alta del lado del Sr. Deán, el Sr. Tesorero le dio la posesión real personal civil del quasi, por la imposición de un bonete en la cabeza, y dicho Sr. Prior dijo la aceptaba, y me pidió de ello testimonio que le ofrecí siendo testigos D. Joseph Agüeria, D. José de la Torre y D. Antonio Polledo y otras varias personas. Luego vueltos al Cabildo y en el asiento correspondiente le renovó la posesión con la misma formalidad dicho Sr. Tesorero, a presencia de la Comunidad, y dicho Sr. Prior la aceptó nuevamente, y me pidió también de ello testimonio, que le volví a ofrecer y se concluyeron dichos actos arrojando al público diferentes monedas en celebridad ${ }^{48}$.

Como resultado de las pruebas el 9 de agosto de 1793, quedó nombrado canónigo, aunque de hecho no tomó posesión hasta el 26 de noviembre en que «el Sr. Vinjoy hizo la posesión de la Fe conforme al Ritual y a Estatutos que juró en la forma acostumbrada» ${ }^{49}$.

$\mathrm{Al}$ año siguiente de su nombramiento como canónigo de la catedral de Oviedo, probó las correspondientes hidalguías por sus cuatro líneas (Fernández Vinjoy, Pérez Penafonte, Díaz de Outeiro y González de Anleo) y la limpieza de sangre ante la Real y Distinguida Orden de Carlos III, con lo cual se le concedió su ingreso como Caballero Supernumerario de la misma por decreto el 30 de marzo de 1794, superando las pruebas el 11 de octubre de $1794^{50}$; este mismo año se empadronaría en Castropol como tal. En la Iglesia

48 Archivo de la Catedral de Oviedo, t. 62 (1789-1794), ff. 132-133, Actas del Cabildo de la Catedral de 7 y 9 de agosto de 1793. Dio fe el a la sazón Secretario don Pedro Manuel Ayala. En celebración de la solemnidad todavía en Figueras de Castropol (Asturias), siendo yo niño y hasta la década de los cincuenta, se practicaba en los bautizos que el padrino del neófito, al salir del templo, arrojase monedas al público, lo cual atraía a casi todos los niños de la parroquia que se tiraban a cogerlas con gran efusión y riesgo, pues llegaban a lanzarse unos encima de otros, todo lo cual constituía un espectáculo.

49 Archivo de la Catedral de Oviedo, t. 62 (1789-1794), f. 152, Actas del Cabildo de la Catedral de 26 de noviembre de 1793.

50 Índice de las pruebas de los caballeros de la Real y Distinguida Orden de Carlos III, desde su institución hasta el año de 1847, Madrid, Archivo Histórico Nacional, 1904, pág. 64. Como tal le incluye también 
ovetense era también caballero de la misma orden el obispo Gregorio Ceruelo de Velasco.

\section{Composición, cargos y rentas del cabildo}

El cabildo de la Iglesia de Oviedo se componía en aquella época de 14 dignidades y 33 canónigos además de los capellanes, ministros para el servicio de altar y coro y otros servidores de culto y administración. Y, aunque vinculado al obispo, se debatía siempre con este por el deseo de independizarse, aun reconociendo la necesidad de colaborar con él.

El cabildo estaba entonces estructurado en deán, chantre, tesorero, maestrescuela, canónigos de oficio (magistral, lectoral, doctoral y penitenciario) y simples canónigos, clasificados en racioneros, medio racioneros y otros beneficios. Entre las clases de oficios se encontraban aquellos que correspondían al obispo (Visitador de Casas, Clavero de las Reliquias y el de la Cera). También estaban los Oficios del Ángulo, denominados así porque sus acuerdos se tomaban en un cabildo de emergencia que se reunía estando colocados los canónigos «en ángulo» en la propia sacristía, sin necesidad de ir a la sala capitular. Y, entre los oficios que ejercían todo lo relacionado con la audiencia, se incluían los jueces, notario escribano, secretario, alcaldes, fiscales, provisor, etc. ${ }^{51}$.

Entre las rentas capitulares que formaban la mesa capitular, estaban singularmente los frutos y rentas de ración (que se dividían entre los miembros del cabildo en función de su jerarquía y comprendían dos raciones: la mayor, con dotación plena; y la menor, con un tercio flotante que se distribuía solo entre los asistentes al cabildo) y las rentas y frutos de préstamos.

Durante los 33 años en que Fernández Vinjoy fue canónigo de Oviedo, si bien parece ser que no ocupó dignidades dentro del cabildo, desempeñó entre otras las comisiones, servicios y oficios siguientes:

En cabildo del 5 de mayo de 1794 se delega en Vinjoy, o persona en su nombre, el asunto del pago contra Ignacio Amor, del concejo de Castropol, sobre una paga de mil reales. Y en el del 28 de junio siguiente, previo escrutinio, salió nombrado Rector Administrador del Colegio de San José, fundado en la catedral en 1662 por el doctor Pedro Díaz de Oseja para niños que no pudieran

Álvarez-Valdés y Valdés, La hidalguía, pág. 164. Puede verse el expediente de Fernández Vinjoy como miembro de esta Orden en AHN, Órdenes civiles, Estado Carlos III, exp. 838 (en red).

51 Para comprender mejor dicha estructura y administración, véase por ejemplo Lope de PASCUAL Martínez, «La vida administrativa del cabildo murciano (s. XIII-XVIII), Memoria Ecclesiae, 4 (1993), págs. 149-167. 
costearse los estudios. ${ }^{52}$ La misión del colegio era formar futuros eclesiásticos con una mejor preparación intelectual. En esta misión el Rector era el encargado de vigilar «que el preceptor desarrollase sus actividades satisfactoriamente y que los colegiales tuviesen un buen comportamiento y estudiasen». También era responsable de velar para que el administrador gestionase adecuadamente las rentas y Obras Pías, que aportaban al colegio una economía precaria y por lo mismo exigían una gran sobriedad en la administración. Con ese cargo, Fernández Vinjoy tenía sobre sí la responsabilidad de la buena marcha del colegio.

De entre esos y demás oficios, el 26 de junio de 1804 Vinjoy fue nombrado Contador de la Ración Menor, cargo para el cual fue reelegido el 28 de junio de $1805^{53}$; pero en 1806 ya le sustituyó el Sr. Ponte. Desempeñó también el de Contador de la Ración Mayor desde el 24 de julio de 1823, siendo reelegido el 4 de agosto de 1825 y el 28 de junio de 1826. Fue designado apuntador el 28 de junio de 1824 junto con el Sr. Grado. Entre otros cargos, desde el 4 de agosto de 1825 formó parte también con el Sr. Babia; y, en ausencia de este, con el Sr. Rubio de la Consulta o delegación (integrada por tres o cuatro canónigos), a la cual el cabildo encomendaba su dictamen en la resolución de los temas más complejos o que llevaría más tiempo discutir. Asimismo, fue juez adjunto de la curia, con voto del obispo, el 28 de junio de 1826, y desempeñó también los cargos de Capitular de Cruzada, sinodal y otros servicios.

\section{Proyectista y opositor a Jovellanos}

Son bien conocidos, aunque no suficientemente elogiados, los esfuerzos de Jovellanos por romper el aislamiento de Asturias con las comunicaciones adecuadas hacia la Meseta ${ }^{54}$ y sus reiterados informes y comunicaciones al respecto. A este fin, en 1769 se decidieron las obras de la carretera de Asturias

52 Archivo de la Catedral de Oviedo, t. 62 (1789-1794), f. 177, Cabildo de 5 de mayo. Sobre dicho colegio pueden consultarse Fermín Canella y Secades, Historia de la universidad de Oviedo y noticia de los establecimientos de enseñanza de su distrito, Oviedo, Universidad de Oviedo, 1904, pág. 57; y Manuel GoRDillo García, «Don Pedro Díaz de Oseja fundador del colegio de San José», Boletín del Instituto de Estudios Asturianos, 132 (1989), págs. 833-898.

53 A partir de 1809 y hasta 1814 no hay asientos en los registros debido a los ajetreos de la Guerra de la Independencia. Constan tales nombramientos en el libro del Archivo de la Catedral de Oviedo Asensoría de los oficios que $[h]$ an de nombrar los Señores del Angulo en este año de mil seiscientos setenta y ocho.

54 De entre la abundante bibliografía al respecto cabe destacar la obra de Joaquín Ocampo SuÁREZVALDÉs, «Caminos y economía. Un informe inédito de Jovellanos sobre la carretera de Castilla», en VV. AA., Estudios dieciochistas en homenaje al profesor José Miguel Caso González, Oviedo, Universidad de Oviedo / Instituto Feijoo de Estudios del Siglo XVIII, 1995, vol. 2, págs. 203-213. 
con Castilla y dos años mas tarde se confirmaba su ejecución de acuerdo con el trazado del arquitecto comisario de Galicia Marcos de Vierna a través de la zona central (desde Oviedo por Olloniego, El Padrún, Mieres, Lena, y Pajares hasta León), ratificado en 1773 por el Ingeniero Fr. Guillermo Cosío.

El tramo de Gijón a Oviedo no se consideró hasta 1782, en que Jovellanos fue encargado de la obra por el Consejo de Castilla, y bajo su dirección se construyeron varias leguas. Pero, aunque firme, la propuesta de dicho trazado hubo diversas reclamaciones y sugerencias en favor de recorridos alternativos: uno de ellos lo presentó precisamente en 1795 el canónigo Vinjoy, a quien a partir de ese momento Jovellanos consideraría uno de sus competidores y atacaría implacablemente. Sobre este proyecto anotó en su diario del 7 de septiembre de 1795, «[s]e hizo tablas la intentona del canónigo proyectista» ${ }^{55}$; y en el del 18 de noviembre: «[i]nforme reservado de los Directores de caminos sobre la disparatada proposición del canónigo Vinjoy» ${ }^{56}$.

Es sabido el tesón con que Jovellanos se enfrentaba con todo aquel que discrepase de sus planes y en especial si estos afectaban a Gijón ${ }^{57}$; pero como por ahora no he intentado localizar ni el proyecto ni el informe del canónigo, ni la replica de Jovellanos, no puedo juzgar las razones, aciertos o discrepancias de uno u otro acerca de este tema. Por lo dicho, este va ser otro de los aspectos que dejo pendiente de estudio en la biografía de Fernández Vinjoy.

\section{La emigración del clero refractario francés}

En 1789 y con motivo de la Revolución Francesa se produjo la entrada masiva en España de numerosos exiliados en su gran mayoría eclesiásticos que se negaron a jurar la Constitución Civil del Clero de 12 de julio de 1790 - por lo que fueron apodados de «refractarios» o «no jurados» y deportados por decreto de la Asamblea Nacional_- Ya a partir de 1790-1792, comenzó su arribada a Asturias, muy en particular a los puertos asturianos con la Ría del Eo a la cabeza, en cuyas márgenes se establecerían 72 eclesiásticos de los pertenecientes al clero refractario ${ }^{58}$, invasión que repercutió en toda la diócesis, con su obispo al frente; pues, si bien muchos de ellos eran edifican-

55 Jovellanos, Obras Completas, t. viI, Diario, 2. ${ }^{\circ}$, pág. 434.

56 Jovellanos, Obras Completas, t. viI, Diario, 2. ${ }^{\circ}$, pág. 484.

57 José Luis Pérez de Castro, «Deseo y esfuerzo de Jovellanos por Gijón», Boletín del Instituto de Estudios Asturianos, 61 (1967), págs. 93-126.

58 María Luisa Meijide Pardo, Sacerdotes franceses emigrados durante la revolución a Galicia, La Coruña, Ediciós do Castro, 1991, págs. 25-29 y 134-135. 
tes, otros, como advertía Pedro Canel Acevedo, «estaban infestados con el espíritu de independencia que les agitaba y que sembraban algunas reliquias de libertad» 59 .

Ante aquella situación era natural que el cabildo catedralicio, al que en 1793 acababa de incorporarse Fernández Vinjoy, compartiese ese problema con el obispo (Juan de Llano Ponte y Sierra) y actuase conjuntamente en un acto de caridad y compañerismo, pese a lo dispuesto en la Real Orden promulgada al respecto. En el cabildo de 29 de agosto de 1794 se dio lectura a una carta del Sr. Obispo, del día anterior en la cual daba parte

[D]e los muchos sacerdotes franceses que van llegando a esta capital y mas pueblos de la diócesis, además de los que estaban con motivo de la irrupción y toma por los franceses de Irún, Fuenterrabía, Rentería, San Sebastián y otros pueblos de la diócesis de Pamplona y Calahorra, y haberles prevenido saliesen de ellos y mas confinantes por observar las primera victimas de la bárbara crueldad a sus hermanos; que los mas o todos se veía en la mayor indigencia y aunque se los había socorrido por de pronto y escrito al Sr. Cardenal Arzobispo de Toledo, cuya respuesta acompañó S.S.I., para tratar que medio y arbitrio se pudiera tomar para el amparo y hospedaje de tales clérigos, nuestros hermanos prófugos de su Patria, por no haber querido asentir a las ideas de sus compatriotas contra nuestra Sagrada Religión y su Monarchía, propone SSI. que el Cabildo se sirva nombrar a el efecto cuatro Sres. Comisarios, los que allí nombró y fueron los Sres. Prior, Robles, Lectoral y yo el Secretario ${ }^{60}$.

Ante hecho tan trascendental, y pese a que el cabildo como institución desempeñó un papel sobresaliente durante la invasión de los curas franceses en Asturias, Fernández Vinjoy no parece haber tomado ninguna actitud notoria, ni aun siendo Castropol, su tierra natal, uno de los puertos mas afectados por el desembarco de 72 clérigos franceses.

\section{El conflicto canónico político}

Al iniciarse en mayo de 1808 el levantamiento en Oviedo del clero asturiano, el obispo de la diócesis, Gregorio de Hermida y Camba, intentó apaciguar

59 Gonzalo Crespo López-Urrutia, «Sobre el clero refractario francés en el Principado (1792-1798)», Boletín del Instituto de Estudios Asturianos, 139 (1992), págs. 147 y sigs.

60 Archivo de la Catedral de Oviedo, t. 62 (1789-1794), Actas del Cabildo de la Catedral de 29 de agosto de 1794 . 
el motín en colaboración con los miembros de la Audiencia. Y a su lado el cabildo de la catedral estuvo también acorde en colaborar con la paz y tranquilidad publicas, «acatar las órdenes del Consejo de Castilla y continuar con las rogativas por la paz» poniéndose al servicio del poder establecido, por cuya actitud mereció la censura y sanciones económicas de la Junta Suprema del Principado de Asturias, la cual exigió al cabildo y a sus canónigos caudales para contribuir a los gastos de la lucha.

En la «Lista de suscripción asturiana para la guerra de Francia» que publicó Canella ${ }^{61}$, tomándola de Canga Argüelles, figura el canónigo Vinjoy con la aportación de 4.000 reales anuales, en tanto otros eclesiásticos contribuyeron con cantidades que oscilaban desde 250 reales a 10.000 que dio el obispo y 15.000 el deán, además de otras sumas y prestaciones a que se obligaron voluntariamente mientras durase la guerra. De la aportación de Vinjoy no podemos deducir ni su generosidad ni su patriotismo ni su entusiasmo al respecto, dado que ignoramos su estatus económico; más bien podemos afirmar que ya por neutralidad o por mera apatía no se distinguió para nada en un bando ni en el otro. No obstante, cuando tuvo lugar la invasión de la ciudad por las tropas napoleónicas, Vinjoy se vio complicado hasta tal punto que hubo de huir y refugiarse en otros pueblos.

A partir de aquel momento ambas instituciones, Iglesia y Junta del Principado, se enfrentaron abiertamente, con excepción de algunos clérigos, pese a que en 1812 el cabildo y el obispo, «mayoritariamente absolutistas», jurasen la Constitución. También las relaciones Iglesia-Estado se entorpecieron, sobre todo a partir del conflicto entre el jefe político Manuel María de Acevedo y Pola ${ }^{62}$ y el obispo Gregorio Hermida y Camba — secundado por una parte del cabildo-, a causa del decreto del 5 de febrero de 1813 que abolía el Tribunal del Santo Oficio de la Inquisición. Frente a dicho decreto, el cabildo alzó una Representación ${ }^{63}$ elevada y firmada por diversos canónigos, de los que se exceptúa entre otros Vinjoy (persona de temperamento ajeno a conflictos), solicitando

${ }^{6}$ Fermín Canella y Secades, Memorias asturianas del año ocho, Oviedo, Ayuntamiento de Oviedo, 1908, pág. 131.

62 Acerca de su personalidad, véase SuÁrez, Escritores y artistas asturianos, pág. 86; Diego Mateo del Peral, «Elecciones y partidos políticos en el Principado durante el reinado de Isabel II (1833-1874)», en Germán Ojeda Gutiérrez (coord.), Historia de Asturias, Salinas, Ayalga, vol. 8, págs. 40-42; Perfecto RodríGuez Fernández, «Jovellanos visto por su contemporáneo y amigo Manuel María Acevedo y Pola», Boletín del Instituto de Estudios Asturianos, 117 (1986), págs. 73-123.

63 Francisco Carantoña Álvarez, "Representación a las Cortes de la Diputación Constitucional de Asturias sobre el destierro del obispo. 6 de enero de 1814», Revolución liberal y crisis de las instituciones tradicionales asturianas (el Principado de Asturias en el reinado de Fernando VII, 1808-1833), Gijón, Silverio Cañada, 1989, págs. 350-351. 
el restablecimiento de dicho Tribunal, ya que el pensar de los firmantes no coincidía ni con las Cortes ni, en consecuencia, con el jefe político ${ }^{64}$.

Esta crisis se agravó cuando Acevedo, valiéndose de su autoridad, quiso imponer en todas las parroquias el que al ofertorio de las misas se diese lectura del Manifiesto en que se explicaba la abolición del Santo Tribunal ${ }^{65}$, algo que se hizo en otras muchas diócesis ${ }^{66}$. La negativa del obispo a obedecer al jefe político finalizó con el exilio del prelado a El Ferrol ${ }^{67}$ por orden de la Regencia del Reino, sacándole de su silla y confinándole allí. Como señala Carantoña ${ }^{68}$, no sería esta la única causa de la ofensiva eclesiástica asturiana contra el sistema constitucional del periodo 1812-1814.

\section{Del sexenio absolutista al trienio liberal}

Fernández Vinjoy, dado su temperamento, no fue persona influyente ni se significó en el Cabildo en épocas monárquicas ni liberales. En pleno sexenio absolutista (1814-1820), apoyó en 1815 al segundo organista suplente e interino de la catedral, Francisco Martínez, que pretendía la plaza titular vacante, y hasta ofrecía dejar a beneficio de la fábrica la mitad de la ración mayor, quedando «responsable a todas las cargas que debe tener un primer organista, así como de pagar al sustituto». Los capitulares Vinjoy y Somoza cursaron una «representación firmada que sería leída el 14 de agosto», haciendo ver que la representación de Francisco Martínez «no era un asunto de pura gracia, como se había creído, por la gran utilidad y ventaja que ofrecía a esta iglesia» y en apoyo de aquel entendían que no debía sacar la plaza a oposición. El cabildo acordó y respondió con un seco y tajante «[n]o ha lugar» que frenó la carrera de Martínez pese al apoyo y sugerencias de Vinjoy ${ }^{69}$.

64 Melquíades Cabal González, «Cómo enfermaron y murieron los obispos de Oviedo», en el Boletín del Instituto de Estudios Asturianos, 119 (1986), págs. 722-724; Francisco Carantoña Álvarez, La Guerra de la Independencia en Asturias, Gijón, Silverio Cañada, 1983, Apéndice 12, págs. 233-236.

65 Mateo del Peral, «Elecciones y partidos políticos en el Principado», págs. 40-42; Carantoña ÁLvarez, La Guerra de la Independencia en Asturias, págs. 233-236.

66 Véase a este respecto la rarísima obra de Bernabe José CABEZA, Memoria interesantes para la historia de las persecuciones de la Iglesia católica y sus ministros en España, Madrid, Imprenta de la Compañía, 1814. (Cit. en Palau y Dulcet, Manual del librero hispanoamericano, ref. a 160.758).

67 Archivo de la Catedral de Oviedo, Caja de Obispos, siglos XIX y Xx, Expediente del Obispo Gregorio Hermida y Camba.

68 CARAntoÑa Álvarez, Revolución liberal y crisis de las instituciones tradicionales asturianas, págs. 109, 114, 142, 148 y 155, entre otras.

69 Raúl Arias del Valle, «Los organistas de la S. I. Catedral de Oviedo (1471-1966)», Studium Ovetense, VIII (1980), pág. 288. 
Tras el sexenio y ya en el segundo periodo constitucional, el trienio liberal (1820-1823), como consecuencia de secundar Oviedo el 28 y 29 de febrero de 1820 la proclamación constitucional de Cabezas de San Juan ${ }^{70}$, se proclamó en la capital la Constitución y se constituyó una Junta de Gobierno Liberal, presidida por Ramón de la Pola, que gobernó hasta el 28 de mayo, en que tomó posesión la nueva Diputación presidida por el repuesto jefe político Manuel María de Acevedo y Pola.

Con este cambio, Fernández Vinjoy volvió a verse atrapado en el cisma y conflicto eclesiástico político provocado en el cabildo como consecuencia de la Real Orden del 26 de octubre de 1820 y Decreto de las Cortes contra los sesenta y nueve diputados realistas que firmaran las de 1814 y habían firmado el 12 de abril la fatídica Representación al rey — conocida como «Manifiesto de los Persas»- para que Fernando VII, a la entrada en España de vuelta de su cautividad, se penetrase del estado de la Nación, del deseo de sus provincias y del remedio que creían oportuno ${ }^{71}$. En aquella Representación, tras un relato crítico de lo ocurrido en España desde 1808 y un elogio de la «monarquía absoluta [, que] es una obra de la razón y de la inteligencia [...] subordinada a la ley divina» ${ }^{72}$, terminaban pidiendo «se proceda a celebrar Cortes con la solemnidad, y en la forma que se celebraron las antiguas» ${ }^{73}$ alertando al rey que no aprobase ni la nueva Constitución ni las demás reformas planeadas en su ausencia, anulando todo lo actuado.

$\mathrm{Al}$ resurgir el constitucionalismo liberal, se consideró a quienes firmaron aquella Representación —entre los cuales se encontraba el obispo de Oviedo, Gregorio Ceruelo de la Fuente- como altamente criminales, y el rey, a consulta de la Junta Provisional, acordó que todos ellos, menos los obispos, fuesen detenidos hasta que las nuevas Cortes decidiesen. En la Real Orden de 26 de octubre y decreto de las Cortes, ya aludidos, se decidiría que se exigiese a los afectados y firmantes que expresasen si se conformaban o no con la resolución. De aceptarla, quedarían en libertad — salvo cualquier otro motivo de privación o condena-, pero al haber perdido la confianza de la nación se les retirarían condecoraciones, honores, cargos y otras gracias; se invitaba además a los obispos y demás eclesiásticos a salir de su diócesis y jurisdicción o retirarse a

70 Sobre este acontecimiento, véase la reacción de algunos conspiradores ovetenses en la hoja de «Meritos y Servicios contraídos por Don Benito Antonio de la Viña», en José Luis Pérez de Castro, Autobiografías de asturianos de los siglos XVI, XVII, XVIII y XIX, Oviedo, RideA, 2009, t. V, págs. 505-519.

71 VV. AA., Representación y manifiesto que algunos diputados a las cortes ordinarias firmaron en los mayores apuros de su opresión en Madrid, Madrid, Imprenta del Collado, 1814.

72 VV. AA., Representación y manifiesto, pág. 49.

73 VV. AA., Representación y manifiesto, pág. 54. 
un convento donde no pudiesen crear conflictos ni comprometimientos, previa toma de razón acerca del valor y producto de las dignidades y prebendas que obtendrían para determinar luego la congrua que pudiera corresponderles. Los que no se conformasen con dichas resoluciones continuarían en seguridad a disposición del Tribunal de las Cortes de resultas del juicio correspondiente, pero suspensos igualmente de honores, cargos y gracias. Y de hecho se ofició a los cabildos para que, sede vacante, nombrasen gobernadores «en sujetos en quienes concurran las cualidades de ser adscritos a las nuevas instituciones y haber dado prueba de ello» ${ }^{74}$.

\section{Obispo y cabildo contra el gobierno}

En cuanto el jefe político superior de Asturias, Manuel María de Acevedo y Pola, recibió del Secretario de Estado, Despacho y Gobernación aquellas disposiciones y, siguiendo las instrucciones de Madrid, acordó en su ejecución dar traslado y conocimiento de las mismas a los afectados y naturalmente al obispo, que permanecía recluido en su palacio de Contrueces. El 21 de diciembre de 1820 las comunicó al cabildo catedralicio de Oviedo ${ }^{75}$, afecto al obispo, donde se recibieron al día siguiente.

Ante ello, se «encargó el estudio de la Orden a la Comisión de oficio, integrada por los doce canónigos de mas categoría» y su dictamen fue que, aunque en sede vacante, correspondía al cabildo la jurisdicción ordinaria; y la administración, a la Iglesia, donde solo siete canónigos «ilustrados» adoptaron posiciones liberales. No obstante, el cabildo, estudiando la gravedad, delicadeza y consecuencias de la Orden, acordó proceder a la elección de los cargos que se le exigían, amparándose en no constarle vacante la sede por cuanto su Ilustrísima no había tomado decisión sobre la respuesta que daría a la Real Orden, por estar esperando órdenes ulteriores y no haber renunciado al cargo ${ }^{76}$.

El prelado, desde Contrueces, comunicó al cabildo el 23 de diciembre su inmediato traslado a León y nombró Gobernador Eclesiástico al provisor, Domingo Vicente de Casas, quien gobernaba desde su confianza.

Llegado el acuerdo del cabildo a conocimiento de Acevedo, considerando este el asunto de la mayor trascendencia, decidió extrañar al obispo, como había

${ }^{74}$ VV. AA., Exposición al augusto congreso nacional hecha por el cabildo de Oviedo en 9 de junio de 1821, Oviedo, Oficina de D. Francisco Pérez Prieto, impresor del Principado, s.f., págs. 11-12.

75 VV. AA., Exposición al augusto congreso, págs. 10-11.

76 VV. AA., Exposición al augusto congreso, págs. 12-13, y Miguel Ángel GonzÁLEz MuÑIz, El clero liberal asturiano, Salinas, Ayalga, 1976, págs. 33-34. 
hecho siete años antes con monseñor Hermida. Y, el 24 de diciembre de 1820 , le sacó de su palacio de Contrueces, obligándosele a caminar toda la noche en el rigor del invierno «con peligro de la vida en medio de bayonetas y a discreción de los que más habían declarado contra su persona» ${ }^{77}$; aunque monseñor Ceruelo advirtió e insistió en que se considerase que no por ello dejaba de ser obispo.

Paralelamente, el 2 de enero de 1821 el jefe político urgió nuevamente al cabildo la elección de gobernadores eclesiásticos que se hiciesen cargo de la diócesis y el 7 de febrero el ayuntamiento elevó a las Cortes una representación quejándose del incumplimiento del decreto del 26 de octubre por parte de la curia diocesana ovetense, y es que, al constarle al cabildo la resistencia del obispo que, aunque ausente, ejercía y reclamaba por medio de su vicario el ministerio pastoral, no se decidía a contrariar al prelado; por lo cual, Acevedo, el 11 de abril de 1821, comunicó al obispo el cese de sus funciones. Y visto que el cabildo continuaba pasivo en la elección de los cargos, el 16 confinó al Vicario General y a varios ciudadanos ${ }^{78}$ en el antiguo colegio de San Vicente y lo imposibilitó de ejercer sus funciones junto a otros sujetos irreconciliables con la Constitución. Esto trastornó al cabildo y forzó a alguno de sus miembros a marcharse, huyendo de la prisión decretada contra ellos, a la vez que lo predispuso a no desobedecer ni retrasar las órdenes políticas. En vista de lo cual Acevedo, ese mismo día 16, decidió pasar personalmente por el cabildo a entregarles la Real Orden, previa solicitud de día y hora para ser recibido con el ayuntamiento y demás autoridades con los honores que les son propios ${ }^{79}$.

Acordado por el cabildo recibirles al día siguiente ${ }^{80}$, el jefe político exigió que aquel mismo día se practicase la elección, y ante ello el cabildo, sin mas dilación «discutió este asunto por todos los puntos de vista que podía considerarse» y procedió a nombrar los Gobernadores y Provisores del Obispado que atendiesen a la administración de la diócesis, eligiéndolos, como exigía la Real Orden, entre los sujetos que habían «dado pruebas de adhesión al nuevo sistema político, y haber estado por la independencia nacional». Tras dicha elección y obligación política, el cabildo creyó un deber eclesiástico hacérselo saber al prelado, reiterándole los nobles sentimientos de respeto y adhesión que siempre le había manifestado. Y aquel, desde Benavente, contestó el 2 de

77 VV. AA., Exposición al augusto congreso, págs. 12-13.

78 VV. AA., Exposición al augusto congreso, págs. 14-15.

79 VV. AA., Exposición al augusto congreso, pág. 13; González MuÑIz, El clero liberal asturiano, págs. 36-38.

80 VV. AA., Exposición al augusto congreso, págs. 13-14. 
mayo desautorizándolos ${ }^{81}$ con un oficio, por lo que el cabildo, indignado y sorprendido por la «inurbana y antipatriótica conducta que descubría su sentido [...] para evitar las funestas consecuencia que podía producir», el mismo día 16 en que la recibió, acordó no contestarla y dar por terminada la comisión de dos capitulares que el prelado tenía a su lado, así como representar a su majestad instruyéndole ${ }^{82}$.

No bien lo habían hecho, cuando el 19 de mayo se vieron sorprendidos por un inesperado papel del obispo ${ }^{83}$ de ese mismo día en que anunciaba su regreso a la diócesis. El cabildo, alarmado, lo puso en inmediato conocimiento del jefe político para que este lo elevase a su majestad, esperando a que esta providenciase consolidando en el cabildo el ejercicio de la sede. Pero el prelado no llevó a cabo su regreso, sin duda bajo amenazas, y debido al temor a represalias por parte de Acevedo. El 13 de junio aceptó los hechos y comunicó que autorizaba al cabildo a nombrar Gobernador «con las facultades que de Derecho competen a mi dignidad ${ }^{84}$.

Sin embargo, el nuncio se negó a reconocer la legitimidad canónica de los Gobernadores electos, por lo cual el cabildo, ante esas fluctuaciones y conflictos, lleno de incertidumbres, el 9 de junio, «consternado de dolor e impelido por el solo bien de la patria, se ve forzado a acudir» con una Exposición al augusto Congreso Nacional, dándole conocimiento de los sucesos, consultándole acerca de los mismos y suplicando la protección de las Cortes para que «como poder supremo legislativo se dignen [...] tomar aquellas medidas que su celo nacional y sabiduría les dicten ser mas propias a la mayor honra de Dios y propiedad de la Patria». Exposición a la cual el Congreso no dio respuesta adecuada, pasando el asunto a la comisión de casos de responsabilidad ${ }^{85}$.

Los vicarios elegidos por el cabildo, entre los cuales no se encontraba Fernández Vinjoy, dando pruebas de adhesión al cargo y al Gobierno, publicaron

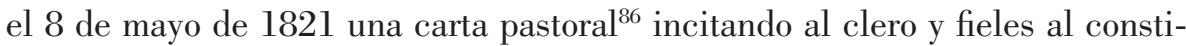
tucionalismo.

Frente a ellos y a su proclama se alzó con ardor y valentía la pluma reaccionaria e intransigente del implacable canónigo magistral y examinador sino-

${ }^{81}$ VV. AA., Exposición al augusto congreso, págs. 5-6 y GonzÁLEz MuÑIz, El clero liberal asturiano, pág. 39 y sigs.

${ }_{82}$ VV. AA., Exposición al augusto congreso, documento 3, págs. 6-9.

83 VV. AA., Exposición al augusto congreso, documento 4, pág. 9.

84 VV. AA., Exposición al augusto congreso, documento 5, pág. 9.

85 GonZález MuÑ̃z, El clero liberal asturiano, págs. 41-43.

86 VV. AA., Carta pastoral de los gobernadores del obispado de Oviedo al clero y pueblo de su diócesis, Oviedo, Oficina de Pedregal y C., 1821. 
dal, el bachiller Pablo Roces Lamuño ${ }^{87}$, quien dirigió también los dardos de su acerada literatura «contra todo cuanto significaba tolerancia y libertad [...] contra todos cuantos invocaban algún principio liberal», por lo que riñó «rudas batallas» dialécticas frente a los gobernadores del obispado «por estimarlos contaminados de liberalismo ${ }^{88}$. Y arremetió principalmente contra «el irreligioso, cismático, escandaloso oficio dirigido por el Jefe Político al Cabildo de Oviedo en 30 de septiembre de $1821{ }^{89}$.

La participación de Fernández Vinjoy en aquellos hechos debió de ser muy pasiva, ya fuese debido a su elevada edad o, más probablemente, a su temperamento y carácter. Su nombre no figura entre los patriotas exaltados que se erguían contra los franceses, y Sandoval ${ }^{90}$ se limita a citarle sin pena ni gloria. Ni se le menciona en el cisma eclesiástico-político entre los canónigos liberales ni entre los reaccionarios constitucionalistas. Tal vez no se viese siquiera afectado por las represalias posteriores surgidas al recuperar Ceruelo de Velasco la sede y todos los poderes de su cargo en junio de 1823, cuando, a su regreso a Oviedo, el obispo ejerció la represión tan duramente, que hasta Calomarde hubo de llamarle a moderación ${ }^{91}$.

\section{Domicilio, defunción y bienes}

En el barrio de la catedral se encontraban las viviendas de la mayoría del clero. En la séptima de la plazuela de la catedral (Parroquia de San Tirso) vivió Fernández Vinjoy sus últimos años ovetenses. Allí figura empadronado en 1815 e

87 Pablo Roces Lamuño, Bosquejo de la carta pastoral expedida por los gobernadores y vicarios generales del obispado de Oviedo en 20 de agosto de 1822, por el Dr. D. Pablo Roces Lamuño, del gremio y claustro de la universidad de Oviedo y canónigo magistral de la Santa Iglesia, Oviedo, Oficina de Fermín Pérez Prieto, 1823. El documento se firma con las siglas E. L. B. C. L. A. R. Sobre el arresto y ejecución de este personaje, vease «Méritos y servicios contraídos por Don Benito Antonio de la Viña» pág. 3, notas 9 y 10, en PÉREZ DE Castro, Autobiografías de asturianos de los siglos XVI, XVII, XVIII y XIX, págs. 505-519.

Sobre el Bachiller y Dr. Pablo Roces Lamuño, magistral de la Santa Iglesia Católica desde el 28 de noviembre de 1812, y fallecido en Oviedo el 19 de septiembre de 1846 (según consignación del Cabildo en Ángulo del día 20) puede consultarse SuÁREZ, Escritores y artistas asturianos, t. VI, págs. 491-492, que resume la Gran Enciclopedia Asturiana, t. XII, pág. 258.

88 SuÁrEZ, Escritores y artistas asturianos, pág. 492.

89 Roces Lamuño, Sentimientos de un católico, apostólico, romano, contra el irreligioso, cismático y escandaloso oficio dirigido al cabildo de Oviedo en 30 de septiembre de 1821 por el jefe político de Asturias, Oviedo, Oficina de Don Fermín Pérez Prieto, 1824, pág. 53. Lo firmó en Oviedo el 30 de diciembre de 1821 con las siglas E. C. A. R. Sobre la deportación del Obispo Ceruelo, puede consultarse GonZález Muñiz, El clero liberal asturiano, págs. 32 y ss.

90 Sandoval y Abellán, La grandiosa empresa de la independencia y el Cabildo Catedral de Oviedo, pág. 81.

91 Raúl Arias del VAlLe, «Proceso del maestro Cuellar», Revista de Musicología, vol. II (1979), pág. 309. 
igualmente en 1824 junto con su sobrino Francisco Vinjoy, estudiante de quince años, y su criada Rita Fernández, de cuarenta. Ocupaban la citada casa, propiedad del cabildo catedralicio, del cual llevaba también en renta un prado y una huerta sitos en la calle de la Vega, en los que había efectuado algunas mejoras ${ }^{92}$.

La vivienda arrendada por Vinjoy parece ser más modesta, por cuanto sabemos, que la de otros eclesiásticos de la catedral que pagaban rentas más elevadas: por ejemplo, Pablo Roces Lamuño, magistral, satisfacía 600 reales de renta por la casa que habitaba en la calle que va al Postigo; Juan Lamuño, lectoral, pagaba 660 por la de la calle Canóniga; Ramón de Llano Ponte, 800 por la de La Ferrería; y Miguel del Riego, 700 por la habitada en la calle San Pelayo durante los años de 1815 a $1831^{93}$.

No me ha sido posible por ahora localizar la partida de defunción de Fernández Vinjoy, pero consta lo siguiente en el Cabildo en Ángulo del 30 de noviembre de 1826:

Reunidos los Sres. Capitulares en número suficiente, presidiendo el Sr. Corado, y siendo testigos los Sres. Corado, Rivadeo ${ }^{94}$, Maestrescuelas y Tesorero, fue anunciada por el Sr. Capellán mayor la muerte de nuestro hermano el Sr. D. Manuel Vinjoy, Canónigo de esta Santa Iglesia y rezado el responso de costumbre, se acordó el entierro para el día de mañana después de horas, para lo que se debería entrar en el Coro a las ocho y media. Asimismo se acordó que el Sr. Capellán Mayor, digo Maestro de Ceremonias, asigne los días que sean hábiles para los demás oficios y que el Sr. Maestrescuela pase aviso a los Sres. hermanos ausentes a fin de que se le apliquen las misas a que están obligados por razón de la hermandad ${ }^{95}$.

No conocemos otros datos más explícitos acerca de su entierro, al que bien pudiera aplicarse la poesía que Antonio Balvidares dedicó al del Canónigo Reguero $^{96}$.

92 En el Archivo de la Catedral de Oviedo, Despacho 45, f. 18, Libro sobre casas y rentas, consta que Vinjoy habitó la séptima casa de dicha plazuela desde 1815 hasta 1826 con una renta anual de 470 reales. Algún año se retrasó en el pago, de ahí que por 1816 y 1817 tuviese que pagar 940 reales, por 1819, 1820 y 18211.410 reales y por 1823 y 1824940 .

93 Datos tomados del Archivo del la Catedral de Oviedo, Despacho 45, ff. 18, 59, 63, 85 y 124, Libro sobre Casas y Rentas.

94 Esta expresión parece referirse a los Arcedianos de Corado y Rivadeo, como igualmente sucedió con la de «Grado». Era frecuente entre el clero designarse por el nombre de los lugares de su jurisdicción en vez de hacerlo por el propio del bautismo.

95 Archivo de la Catedral de Oviedo, t. 62 (1820-1827), f. 174, Libro de Acuerdos Capitulares. Cabildo de 30 de noviembre de 1826. Firma Manuel Pérez Suárez.

96 Antonio Balvidares, «El entierro del canónigo Reguero», en José Caveda y Nava (ed.), Colección de poesías en dialecto asturiano, Oviedo, Imprenta de D. Benito González y Compañía, 1839, págs. 92-100. 
Tras las honras fúnebres adecuadas a su rango, Fernández Vinjoy fue sepultado en la capilla de Santa Eulalia de la catedral, donde actualmente ya no se localizan sus restos, pues tan solo están identificadas las tumbas de cuatro obispos. Cabe suponer que los restos de Fernández Vinjoy y de algún catedralicio más fueran trasladados de lugar o quedasen ocultos por el embaldosado realizado en la capilla con intervención del canónigo capitular Juan de la Cruz Ceruelo de Velasco, Gobernador del Obispado y Prior, y de Víctor Ceruelo de Velasco, último arcediano de Ribadeo, secretario de cámara y gobierno del obispo, los cuales realizaron aquella obra en cumplimiento de la voluntad de su tío el prelado, fallecido en 1836.

Era frecuente que cada canónigo fallecido legase una parte de sus bienes a la Catedral, y al efecto de tales mandas existía un libro registro; pero los bienes de Fernández Vinjoy debieron ser muy escasos a juzgar por las reclamaciones que a su fallecimiento hicieron al cabildo sus sobrinos y herederos, como pasamos a recordar.

Para cubrir la vacante del fallecido Vinjoy, ya en Cabido del 7 de diciembre de 1826, se nombra contador mayor de ración al Sr. Lueje y se acuerda el anuncio de estilo para dar en el Cabildo del lunes el prado y huerta que llevaba, concediendo además la casa para vivir a Villamil, en caso de que no haya otro más antiguo que la quiera ${ }^{97}$.

Y tras otros acuerdos relacionados con la huerta, el del 19 de enero de 1827 dice:

Desde el acta capitular en que consta el arriendo que se le hizo de la huerta, que el Sr. Vinjoy llevaba en la calle de la Vega, y en vista de que por ella no consta que haya emprendido las mejoras que tiene con acuerdo del Cabildo, ni que se le hayan ofrecido abonar, se acordó abonarle solo lo que pueda valer la cerca que tiene y le echó el difunto, y para que se arriende con el debido conocimiento se encargó a la contaduría tome los informes correspondientes sobre el precio en que pueda hacerse $\mathrm{e}^{98}$

No contentos los herederos de Vinjoy con dicho acuerdo, tomaron nuevas decisiones y, ante ello, en el cabildo de 26 de enero de 1827 se anotó: «[l]eído un escrito en que los herederos del Sr. Vinjoy piden se les abonen todas las mejoras que su difunto tío hizo en la huerta; se acordó no haber lugar a la solicitud». Y en cabildo del 9 de febrero se adjudicó el arriendo de la huerta, por orden de

97 Archivo de la Catedral de Oviedo, Despacho 45, f. 174, Libro sobre Casas y Rentas.

98 Archivo de la Catedral de Oviedo, Despacho 45, f. 174, Libro sobre Casas y Rentas. 
antigüedad a Miguel Hermida, en renta de 320 reales y con la condición expresa de no subarrendarla, en ningún tiempo, a nadie fuera de la comunidad ${ }^{99}$. No obstante, los herederos de Vinjoy continuarían con sus reclamaciones ${ }^{100}$.

Pese a lo expuesto, quedan aún pendientes de estudio diversos aspectos de la personalidad y obra de Fernández Vinjoy, como el análisis paralelo de sus traducciones con las efectuadas por otros traductores de Filón y algunos más que tengo en vías de completar, de los cuales prescindo por el momento para no dilatar más el dar a conocer o al menos difundir la personalidad de tan ilustre como olvidado castropolense.

99 Archivo de la Catedral de Oviedo, Despacho 45, ff. 179-180, Libro sobre Casas y Rentas, cabildos de 5 y 9 de febrero de 1827.

100 Archivo de la Catedral de Oviedo, t. 26 (1820-1827), f. 186, Libro de Acuerdos Capitulares. Cabildo de 30 de noviembre de 1826. 
